\title{
Minocycline hydrochloride (Minocin) as a single-dose oral treatment of uncomplicated gonorrohea in men
}

\author{
G. MASTERTON AND C. B. S. SCHOFIELD \\ Department of Sexually-Transmitted Diseases, 67 Black Street, Glasgow G4 OEF
}

\section{Summary}

349 male patients with uncomplicated gonococcal urethritis were treated with a single dose of $300 \mathrm{mg}$. or $400 \mathrm{mg}$. minocycline hydrochloride.

The lower dose gave a lower failure rate, $3 \cdot 2$ compared with $5 \cdot 1$ per cent., but this difference was not statistically significant. The overall known failure rate of 4.2 per cent. compares most favourably with our previous findings in this area using other drugs of the tetracycline group. The incidence of post-gonococcal urethritis $(5 \cdot 1$ per cent.) was also the lowest we have found. The few side-effects reported were comparatively trivial.

Because of its high degree of therapeutic efficacy, the relative lack of side-effects, and the reduced incidence of post-gonococcal urethritis, minocycline hydrochloride should be considered the drug of choice whenever single-dose oral treatment is given in uncomplicated gonorrhoea in men.

\section{Introduction}

The increasing relative resistance of gonococci to penicillin has meant that over the years the dose has had to be increased at regular intervals to remain effective. Some centres have already used as much as 5 m.u. penicillin with probenecid to treat gonorrhoea (Gray, Phillips, and Nicol, 1970). This is thirty times the amount of the crude penicillin which gave satisfactory cure rates in the early 1940 s.

Phillips, Rimmer, Ridley, Lynn, and Warren (1970) pointed out that the dose of penicillin could not be increased indefinitely in this fashion and urged that the search for alternatives should continue.

Sharing this opinion, we have concentrated upon the tetracycline groups as no relative resistance to them has been noted among the strains of gonococci isolated locally (Laidlaw, 1973). Several broad-spectrum antibiotics have been evaluated in this department (Masterton and Schofield, 1972 ; Masterton, Scho-

Received for publication May 23, 1975 field, and Tait, 1973 ; Schofield and Masterton 1974) ; the failure rates have been acceptably low, but side-effects have sometimes been troublesome.

Minocin (minocycline hydrochloride) is a new semi-synthetic tetracycline which has been the subject of several investigations. Duncan, Glicksman, Knox, and Holder (1971) compared minocycline with tetracycline against strains of Neisseria gonorrhoeae. The minimum inhibitory concentrations (MIC) of minocycline and tetracycline were in the same general range (median MIC of $0.5 \mu \mathrm{g} . / \mathrm{ml}$. for each). In clinical trials of minocycline so far carried out, failure rates in gonococcal urethritis have varied from 25 per cent. (Duncan and others, 1971) to 4.5 per cent. (Thatcher, Pazin, and Domescik, 1970).

The present study compares the efficacy of two single-dose schedules in the treatment of uncomplicated gonorrhoea in men. The design of the trial was identical with that of our previous studies of broad-spectrum antibiotics.

\section{Material and methods}

349 male patients with uncomplicated gonococcal urethritis were treated with minocycline hydrochloride, alternate patients being given either three tablets $(300 \mathrm{mg}$.) or four tablets $(400 \mathrm{mg}$.) in a single dose. Patients with complicated infections, known previous defaulters, and those in transit were excluded from the study.

Of the 349 men suffering from uncomplicated gonorrhoea, 95 (27 per cent.) were married and 254 ( 73 per cent.) were born in the United Kingdom ; 36 (10 per cent.) were teenagers and a further 159 (46 per cent.) were under 30 years of age.

A presumptive diagnosis of gonorrhoea was made by examining Gram-stained smears of urethral exudate. The diagnosis was confirmed by culture, and the MIC of penicillin $G$ for each strain was determined, and also its sensitivity or resistance to tetracycline, streptomycin, kanamycin, and sulphafurazole (Table I).

Similar laboratory investigations to those described above were adopted for all patients with posttreatment urethritis.

The tablets were given with a drink of water under supervision in the clinic. It was planned to re-examine the patients on day $2,4 / 5,8,15$, and 29 after treatment. 
TABLE I Initial sensitivities of infecting gonococci

\begin{tabular}{|c|c|c|c|c|}
\hline \multirow{2}{*}{$\begin{array}{l}\text { MIC }(\mu g . / m l .) \\
\text { of penicillin } G\end{array}$} & \multicolumn{2}{|c|}{ Strains } & \multicolumn{2}{|c|}{ Number of strains resistant to: } \\
\hline & No. & Per cent. & Streptomycin & Sulphafurazole \\
\hline 0.03 & 269 & $77 \cdot 1$ & 16 & 0 \\
\hline 0.06 & 44 & $12 \cdot 6$ & 12 & 0 \\
\hline $0 \cdot 15$ & 20 & $5 \cdot 7$ & 6 & 7 \\
\hline 0.3 & 8 & $2 \cdot 3$ & 1 & 3 \\
\hline 0.6 & 6 & $1 \cdot 7$ & 5 & 4 \\
\hline $1 \cdot 2$ & 2 & 0.6 & 1 & 1 \\
\hline Total & 349 & $100 \cdot 0$ & 41 ( 11.7 per cent.) & 15 ( 4.3 per cent.) \\
\hline
\end{tabular}

N.B. No strain was resistant to tetracycline or kanamycin.

TABLE II Cumulative results

\begin{tabular}{|c|c|c|c|c|c|c|}
\hline \multirow[b]{2}{*}{ Day } & \multirow[b]{2}{*}{$\begin{array}{l}\text { No. on } \\
\text { surveillance }\end{array}$} & \multirow[b]{2}{*}{$\begin{array}{l}\text { Last } \\
\text { attendance }\end{array}$} & \multicolumn{4}{|c|}{ Reason for withdrawal from trial } \\
\hline & & & $\begin{array}{l}\text { Subsequent } \\
\text { default }\end{array}$ & $\begin{array}{l}\text { Post-treatment } \\
\text { NSU }\end{array}$ & Re-infection & $\begin{array}{l}\text { Treatment } \\
\text { failure }\end{array}$ \\
\hline $\begin{array}{l}1 \\
2 \\
4 / 5 \\
8 \\
15 \\
22 \\
29\end{array}$ & $\begin{array}{l}349 \\
328 \\
281 \\
246 \\
229 \\
220 \\
216\end{array}$ & $\begin{array}{r}21 \\
47 \\
35 \\
17 \\
9 \\
4 \\
216\end{array}$ & $\begin{array}{r}21 \\
38 \\
24 \\
6 \\
2 \\
2 \\
0\end{array}$ & $\begin{array}{l}0 \\
6 \\
4 \\
6 \\
0 \\
0 \\
0\end{array}$ & $\begin{array}{l}0 \\
0 \\
0 \\
2 \\
7 \\
2 \\
0\end{array}$ & $\begin{array}{l}0 \\
3 \\
7 \\
3 \\
0 \\
0 \\
0\end{array}$ \\
\hline Total & & 349 & 93 & 16 & 11 & 13 \\
\hline
\end{tabular}

\section{Results}

Because of erratic attendance, the routine examination planned for the month after treatment was not always possible ; 21 ( 6 per cent.) of the patients failed to return after treatment, 68 more defaulted within the first 2 weeks, and four during the second fortnight. However, 216 (62 per cent.) did complete the 4 weeks' surveillance satisfactorily (Table II).

Of the 328 patients who returned after treatment, sixteen ( $5 \cdot 1$ per cent.) had, or developed, non-specific urethritis. Of the remainder, $24(7 \cdot 7$ per cent.) still had, or developed, a gonococcal urethritis after treatment. As with the initial infections, gonococci were identified by microscopy but the findings were always confirmed by culture. Eleven ( 3.5 per cent.) of these patients were considered to have been re-infected because of admitted re-exposure to risk of infection and a significant alteration in the antibiogram. The remaining thirteen ( 4.2 per cent.) were regarded as treatment failures because they denied re-exposure to risk and the second anti- biogram was similar to the original one. The results of the two treatment schedules are compared in Table III. Although there is a lower failure rate among those given $300 \mathrm{mg}$. Minocin ( 3.2 per cent.) than in those given $400 \mathrm{mg}$. ( $5 \cdot 1$ per cent.), the difference did not reach statistical significance $\left(\chi_{1}^{2}=0.72 ; 0.4>P>0.3\right)$.

Side-effects were minimal and insignificant. Five ( 1.5 per cent.) of the 328 patients who returned after treatment had complaints, two of dizziness and three of nausea. No patient complained of vomiting or diarrhoea.

Of the 349 strains of gonococci, 36 (10.3 per cent.) required an MIC of penicillin $G$ in excess of 0.1 $\mu \mathrm{g} . / \mathrm{ml}$. No strain was resistant to tetracycline or kanamycin.

\section{Discussion}

The known treatment failure rate in uncomplicated gonorrhoea in this trial was 4.2 per cent., the lowest

TABLE III Analysis of the two treatment schedules

\begin{tabular}{|c|c|c|c|c|c|c|}
\hline \multirow{2}{*}{$\begin{array}{l}\text { Dosage of } \\
\text { minocycline } \\
\text { hydrochloride } \\
\text { (mg.) }\end{array}$} & \multirow{2}{*}{$\begin{array}{l}\text { Total } \\
\text { treated }\end{array}$} & \multirow{2}{*}{$\begin{array}{l}\text { Number } \\
\text { followed-up }\end{array}$} & \multirow{2}{*}{$\begin{array}{l}\text { Post-treatment } \\
N S U\end{array}$} & \multirow[b]{2}{*}{ Re-infected } & \multicolumn{2}{|c|}{ Treatment failures } \\
\hline & & & & & No. & Per cent. \\
\hline $\begin{array}{l}300 \\
400\end{array}$ & $\begin{array}{l}173 \\
176\end{array}$ & $\begin{array}{l}164 \\
164\end{array}$ & $\begin{array}{l}8 \\
8\end{array}$ & $\begin{array}{l}6 \\
5\end{array}$ & $\begin{array}{l}5 \\
8\end{array}$ & $\begin{array}{l}3 \cdot 2 \\
5 \cdot 1\end{array}$ \\
\hline
\end{tabular}


TABLE IV Comparison of results of several single-dose oral treatments of uncomplicated gonorrhoea in men

\begin{tabular}{|c|c|c|c|c|c|c|}
\hline Year & Drug & Dosage & $\begin{array}{l}\text { No. of } \\
\text { patients }\end{array}$ & $\begin{array}{l}\text { Known } \\
\text { failure rate } \\
\text { (per cent.) }\end{array}$ & $\begin{array}{l}\text { Post-treatment } \\
N S U \text { (per cent.) }\end{array}$ & $\begin{array}{l}\text { Side- } \\
\text { effects } \\
\text { (per cent.) }\end{array}$ \\
\hline $1969 / 70$ & $\begin{array}{l}\text { Vibramycin } \\
\text { (capsules) }\end{array}$ & $300 \mathrm{mg}$. & 107 & $6 \cdot 4$ & $7 \cdot 8$ & $3 \cdot 5^{a}$ \\
\hline 1970 & $\begin{array}{l}\text { Deteclo } \\
\text { (tablets) }\end{array}$ & 1.2 to $2 \cdot 4 \mathrm{~g}$ & 220 & $7 \cdot 1$ & $9 \cdot 8$ & $16 \cdot 0^{b}$ \\
\hline 1974 & $\begin{array}{l}\text { Minocin } \\
\text { (tablets) }\end{array}$ & $\begin{array}{l}300 \text { or } \\
400 \mathrm{mg} .\end{array}$ & 349 & $4 \cdot 2$ & $5 \cdot 1$ & 1.5 \\
\hline
\end{tabular}

sTaken with milk

Using metaclopromide monohydrate $(5 \mathrm{mg}$.) as an antiemetic

we have obtained in any similar trial to date. There was no apparent clinical advantage in giving four tablets rather than three, the results being similar. Because we invariably follow the same criteria in all drug trials, it is possible to compare the results of this one with those carried out previously (Table IV). The failure rate was the lowest we have obtained, as was the incidence of post-treatment non-specific urethritis ( $5 \cdot 1$ per cent.) and of side-effects $(1.5$ per cent.).

The comparative absence of side-effects was particularly impressive. It is conceivable that a few patients, gratified by the rapid disappearance of symptoms, may have ignored minor upsets after therapy, but such magnanimity is not a characteristic of the local patients. It is firmly believed that minocycline hydrochloride, used in single doses as described, produces relatively few minor side-effects and is very effective therapeutically.

Minocycline hydrochloride was not included in the sensitivity tests, but Steigbigel, Reed, and Finland (1968) and Duncan and others (1971) have shown that the sensitivity of the gonococcus to this drug is similar to tetracycline.

We wish to thank Messrs. Lederle Ltd. supplying the minocycline hydrochloride for use in this clinical trial.

\section{References}

Duncan, W. C., Glicksman, J. M., Knox, J. M., and HOLDER, W. R. (1971) Brit. F. vener. Dis., 47, 364

Gray, R. C. F., Phillips, I., and Nicol, C. S. (1970) Ibid., 46, 401

LAIDLAW, M. (1973) Lab. Equipmt Dig., 61A, 50

Masterton, G., and Schofield, C. B. S. (1972) Brit. F. vener. Dis., 48, 121

Opinion, 1, 207

Phillips, I., Rimmer, D., Ridley, M., LyNN, R., and WARREN, C. (1970) Lancet, 1, 263

SChofield, C. B. S., and Masterton, G. (1974) Brit. F. vener. Dis., 50, 303

Steigbigel, N. H., REed, C. W., and Finland, M. (1968) Amer. F. med. Sci., 255, 179

Thatcher, R. W., Pazin, G., and Domescik, G. (1970) Publ. Hlth Rep. (Wash.), 85, 160 